\title{
Woodlands of the past - The excavation of wetland woods at Zwolle-Stadshagen (the Netherlands): Growth pattern and population dynamics of oak and ash
}

\section{U. Sass-Klaassen ${ }^{1,2} \&$ E. Hanraets ${ }^{1}$}

1 Netherlands Centre for Dendrochronology, Ring Foundation, P.0. Box 510, 8200 AM Lelystad, the Netherlands

2 Wageningen University, Centre for Ecosystem Studies, Forest Ecology and Forest Management, P.0. Box 47, 6700 AA Wageningen, the Netherlands. Corresponding author. Email: ute.sassklaassen@wur.nl

Manuscript received: October 2003; accepted: February 2006

\begin{abstract}
Dendrochronology has been used to date sub-fossil wood excavated from former wetland woods located in Zwolle-Stadshagen, the Netherlands. Tree-ring analysis was performed on oak and ash to gain insight into changes in the growth dynamics of the trees resulting from changes in external site conditions, particularly hydrology. In addition population dynamics of oak and ash were studied by observing the temporal distribution and mean age of the oak and ash trees in the period when the woodland existed. The results showed that woodlands with oak and ash at Zwolle-Stadshagen existed at least for a period of about 700 years, from ca. 150 BC to AD 580 (ca. 2200 - 1400 cal. BP). The oak and ash were slowly growing and showed alternating phases of normal and depressed growth. Growth depressions occurred with a frequency of about 20 to 40 years. Almost all of these depressions were synchronous with those in oaks from other - mainly wetland areas - in NW Europe. Consequently, a regional (climate) factor must be considered responsible for this phenomenon. By taking into account the specific growth conditions in wetland woods it is very likely that this factor is linked to site hydrology. Around AD 300 (ca. 1650 cal. BP) a remarkable shift in population dynamics occurred in both oak and ash with many new trees establishing. This indicates a period of striking changes in site hydrology preceding the collapse of the woodland starting around AD 530 (ca. 1420 cal. BP).
\end{abstract}

Keywords: Dendrochronology, oak, ash, population dynamics, (palaeo)climate

\section{Introduction}

\section{Research on sub-fossil bog oak}

During the last 20 years a lot of research has been conducted on sub-fossil oak. Due to its relatively high resistance against fungal and bacterial attack oak wood is often the only species that is suitable to apply dendrochronological dating. The oaks grew in wetland woods in Germany, Ireland and the Netherlands and have been preserved in situ in peat, sometimes for thousands of years (Leuschner et al., 2002). The NW European dataset consists of tree-ring series of about 2600 sub-fossil bog oaks from approximately 200 sites. Absolutely dated treering chronologies have been derived from sub-fossil oak extending from $6069 \mathrm{BC}$ to the tenth century $\mathrm{AD}$ (Pilcher et al., 1984; Leuschner, 1992; Jansma, 1995; Spurk et al., 1998).
More recent findings in Ireland could even be dated to the 17th century (Baillie, personal communication.). The Dutch bog-oak chronologies have in the first instance been built up for dating wood from the archaeological context (Jansma, 1996). However, the striking similarity between bog-oak chronologies from the Netherlands and Germany and even Ireland indicates the existence of a large-scale regional factor, e.g. an aspect of climate that influenced the growth of oak in former wetland woods on different sites in NW Europe in the same way. Leuschner et al. (2002) found moreover synchronous population dynamics, i.e. phases of germination and dying-off (GDO), in oaks from different sites in NW Europe throughout long periods of the Holocene. Bog-oak chronologies extend far back in time, almost to the re-immigration of oaks after the last Ice Age (Friedrich et al., 2004). Moreover these oaks are considered to be sensitive indicators of changing 
ecological conditions because they were growing under temporarily extremely wet site conditions. This makes that these chronologies are promising proxy (= indirect) data for climate.

\section{Growth pattern of bog oaks and its interpretation in terms of climate}

Most sub-fossil bog oaks were generally slow growing and showed a characteristic tree-ring pattern with alternating periods of normal growth and prolonged growth depressions. Considering the specific site conditions with a high groundwater level prevailing throughout the growing season it is likely that site hydrology played an important role in the growth and population dynamics of these oaks.

Up to now, the interpretation of this specific tree-ring pattern in terms of (changing) site factors, e.g. hydrology, has been problematic since no modern woodlands seem to exist any more in NW Europe in which oak with this specific growth pattern can be found (Sass-Klaassen, 2003, 2004). To identify those ecological (site) factors that mainly influence tree growth the wetland woods with oaks have to be reconstructed. The only chance of explaining the tree-ring pattern and population dynamics of the oaks is to collect as much information as possible about the ecological setting in these woodlands were oaks have been preserved. Hence an interdisciplinary project was initiating whereby an ancient woodland in ZwolleStadshagen was excavated in order to reconstruct the development, structure and dynamics of the (woody) vegetation in its environmental context including the investigation of peat development and site hydrology (Kooistra et al., 2006).

Dendrochronology was in first instance used to date the remains of oak (Quercus robur) - and if possible ash (Fraxinus excelsior) - that were sufficiently preserved in the peat layer. By dating the single tree-ring series of the excavated oak and ash trees information about the temporal and ecological context in which these trees grew can be achieved. In a second step the temporal distribution of the dated tree-ring series was used to study the population dynamics in bog oak and ash indicated by e.g. accumulated phases of germination and/or dying-off (GDO). The mean age of all trees of a population in every calendar year served as an integrating parameter to identify shifts in population dynamics (Leuschner et al., 2002). The dendrochronological results were related to information from the palynological and the soil records to answer the following research questions:

1. When and for how long did a wetland wood with oak and ash exist around Zwolle-Stadshagen?

2. Which ecological site factor(s) can be linked to phases of normal and depressed tree growth?

3. Are these growth influencing ecological factors local or regional, i.e. are they triggered by a large-scale regional factor, i.e. climate?
4. When did major changes in site ecology indicated by shifts in population dynamics take place in the woodlands of Zwolle-Stadshagen?

5. Do these changes in site ecology reflect a site specific, i.e. local or a large-scale regional phenomenon?

\section{Material and Methods}

\section{Sample site, samples and sampling}

Sampling was done at the excavation site in ZwolleStadshagen in two experimental trenches and four excavation trenches with a total area of approximately $1270 \mathrm{~m}^{2}$ (see Kooistra, et al., 2006). Stem discs of $5 \mathrm{~cm}$ thickness were taken by using a chain saw and subsequently sealed in plastic bags to prevent desiccation.

Out of the about 500 wood remains that were sampled only about 100 were suitable for dendrochronological analysis. Restrictions defining the suitability for dendrochronological investigation were the state of preservation, the number of tree rings and the tree species. Preferably well-preserved stem discs were taken from the base of the trees. These discs contain the whole tree-ring sequence from the centre of the tree (= pith) to the last-formed tree ring under the bark. Based on this material a good estimation can be made of the year of germination and dying-off and hence the age of the tree. Long tree-ring series provide the possibility to study tree growth in response to changing site conditions. However, since the stems were not always sufficiently preserved, other tree remains like branches and roots were also analysed. It is evident that the wood remains had to be preserved in such a way that tree rings were still visible and measurable. A suitable sample should contain at least 30 tree rings. Up to now, oak (Quercus robur) and pine (Pinus sylvestris) are the most suitable species for dendrochronology when considering sub-fossil material; hence long chronologies have been derived for these two species (e.g. Leuschner et al., 2002; Spurk et al., 2002; Friedrich et al., 2004). However, other species such as ash (Fraxinus excelsior), alder (Alnus), elm (Ulmus), and beech (Fagus sylvatica) can also be dated if checking site chronology (= mean curves) of these species against an oak chronology from the same site (Billamboz, 1996, 2002).

\section{Dendrochronological analysis}

\section{Preparation, measurement, dating, and calculation of site chronologies}

The surface of the wood samples was carefully prepared with razor blades in order to make the tree rings visible. Tree-ring width was measured with dendrochronological measuring equipment (LINTAB, TSAP; Rinn, 1996) with a precision of 1/100 mm.

In order to get an indication of the year of germination and dying-off for every single tree the number of missing rings to 
the bark and the pith was estimated, taking into account aspects such as the number of remaining sapwood rings, the course of the tree rings close to the pith, the shape and morphology (stem, root, branch) of the sample as well as the position of the sample in the tree (distance from the stem base). However, it has to be admitted that the precision of these estimates was sometimes restricted by the poor state of preservation.

All single tree-ring series were statistically (cross-) checked on the computer by using programmes TSAP (Rinn, 1996) and COFECHA (Holmes, 1983; Grissino-Mayer, 2001), and visually by comparing the plotted series on the screen. Both programmes also provide a statistical description (mean tree-ring width, standard deviation and autocorrelation) of the single tree-ring series.

Subsequently, so-called site chronologies (= mean curves) were calculated from the single tree-ring series of the oaks and ashes, respectively. These site chronologies reflect the common (high and low frequency) variation in the tree-ring series of all trees from a specific site (Fritts, 1976). Before calculating the site chronologies the single tree-ring series were detrended in order to get rid of tree-individual (lowfrequency) variance, namely the age-related growth trend, and to maximise the common signal in the tree-ring series. For this purpose the series were logarithmically transformed and then filtered by a dynamically weighted moving average (variable kernel filter of 101 years). By doing so, intervals with a large variance, such as abrupt changes in the growth rate, are filtered more intensively than smooth intervals that show little variance (Riemer, 1994). The site chronologies of oak and ash were calculated as arithmetic average of the detrended tree-ring series. These site chronologies express the common growth pattern of all sampled trees, including pronounced phases of growth depression and release.

\section{Dating of tree-ring series}

Dating of the single tree-ring series of oak and ash as well as the two site chronologies was done by comparison with the socalled NW European bog-oak chronology. This regional chronology is compiled from tree-ring series of about 600 subfossil oaks from different sites in NW Germany and the Netherlands (Leuschner, Sass-Klaassen, unpubl. data). Comparison was done by using different statistical test, i.e. student t-test, coefficient of parallel run and correlation analysis (programme TSAP, Rinn, 1996).

The similarity between the regional and the site chronologies was visually checked by plotting the chronologies together according to the results of the statistical analysis.

\section{Differentiation between local and regional variation in the site chronologies}

In order to evaluate whether striking features in the two (oak and ash) Zwolle chronologies are the result of local or regional phenomena the two site chronologies from Zwolle were compared in detail with the NW European bog-oak chronology (see above). Common features in the Zwolle chronologies and the regional chronology point to large-scale regional factors as a trigger for variation in tree growth, whereas differences between the chronologies indicate that local site factors mainly determined the growth of the trees during these periods.

\section{Population dynamics}

\section{Temporal distribution of trees and calculation of mean-age chronologies}

Information on the germination and dying-off of the oaks and ashes was used to reconstruct population dynamics.

First, the temporal distribution of all dated oak and ash trees was visualised in a plot whereby every individual tree was represented as a time series reflecting its life span from germination to death.

Second, the mean-age value was calculated to detect abrupt changes in the tree populations, e.g. successive woodland generations. The mean-age value for each given year was calculated as the arithmetic mean of the age of all single trees in this specific calendar year. Sudden changes in the courses of the two derived mean-age chronologies for Zwolle would indicate a change in the oak and/or ash tree population. To point out the long-term growth variations of the two meanage chronologies a (parabolic) weighted 15-year running mean was applied as a low-pass filter. The mean-age chronologies were graphically compared to outline synchronous behaviour in germination and dying-off in the oak and ash populations. The results were compared to the pollen and soil record to detect possible temporal relationships and - if so - to explain changes in mean age in terms of changing site conditions.

\section{Results}

\section{Sample quality - conservation}

About $60 \%(60)$ of the oak and 15\% (40) of the ash samples were suitable for dendrochronological analysis and almost all of them could be dated. The high rate of (datable) oak was partly due to the fact that in trenches 1 and 2 (= trenches for preliminary survey) selective sampling was done on oak for dendrochronological analysis (see Kooistra et al., 2006). Treering analysis of the alder samples was not possible because of the poor conservation of the samples. Poor conservation of the material also meant that most oak and ash samples lack the outermost and - to a lesser extent - the innermost tree rings. 0nly some oaks, mainly originating from trenches 1 and 2, contained sapwood, meaning that only a few rings were missing to the bark. After the estimate of missing rings to the bark and the pith it became obvious that both oak and ash could reach a substantial age; the oldest oak and ash were respectively 343 and 245 years old. 
Table 1. Number of suitable oak and ash samples for dendrochronology and statistical features.

\begin{tabular}{|c|c|c|c|c|c|c|c|c|c|}
\hline \multirow[t]{2}{*}{ Species } & \multirow[t]{2}{*}{ Total } & \multicolumn{2}{|c|}{ Number of suitable samples } & \multicolumn{3}{|c|}{ Tree Age } & \multirow[t]{2}{*}{ Mean TRW (mm) } & \multirow[t]{2}{*}{ Mean std. } & \multirow[t]{2}{*}{ Mean Auto-corr. } \\
\hline & & Dated & Undated & Mean & Min. & Max. & & & \\
\hline Oak & 103 & 59 & 5 & 165 & 65 & 343 & 0.87 & 0.76 & 0.49 \\
\hline Ash & 215 & 36 & 7 & 133 & 61 & 245 & 0.57 & 0.25 & 0.72 \\
\hline
\end{tabular}

\section{(Statistical) characteristics of the tree-ring series}

The mean tree-ring width (TRW) of the oaks and the ashes amounted to $0.87 \mathrm{~mm}$ and $0.57 \mathrm{~mm}$, respectively (Table 1). 0n average both species were very slow growing in comparison to modern oaks from wet and drier sites, where the mean treering widths varied between 2 and $3 \mathrm{~mm}$ (Sass-Klaassen, 2004). However, a huge variability in tree-ring width (see standard deviation (STD) in Table 1) occurred due to alternating periods of wide and extremely narrow tree rings (Figs 1 and 2). This low-frequency variation also causes the relative high values of autocorrelation (see Table 1) even if both species showed almost no age trend, i.e. a steady decrease of tree-ring widths with increasing age.

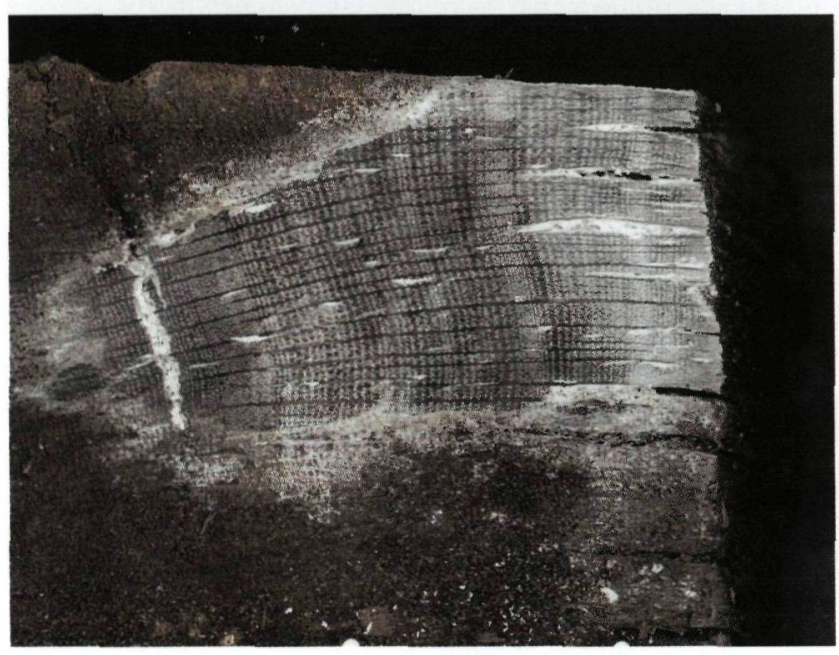

Fig. 1. Surface of a sub-fossil oak with periods of normal and depressed growth with, respectively, wide and narrow rings.
All the oaks and most of the ashes showed a characteristic growth pattern with alternating periods of growth depression and growth release, like it has been described as typical for bog oaks (e.g. Leuschner et al., 2002). Most of these growth variations were synchronous in all oaks and - less pronouncedly in the ashes (Fig. 3). Growth depressions started rather abruptly and could last up to 20 years. They occurred during all phases of the trees' lives, i.e. in juvenile and adult trees (Figs. 2 and 3). In figure 3 and 4 it is obvious that growth depressions occur about every 20 to 40 years - throughout the whole period of at least 700 years when a woodland existed in Zwolle-Stadshagen.

It is noteworthy that the few oaks and ashes containing sapwood or wood wane (last tree-ring under the bark) all showed growth depressions prior to their dying-off.

\section{Dating and temporal distribution of oak and ash}

The tree-ring series of oak were dated with the NW European bog-oak chronology to the period between $131 \mathrm{BC}$ and AD 567 (2082 - 1383 cal. BP), whereas the ash samples dated somewhat later, between AD 58 and AD 527 (1892 - 1423 cal. BP)(table 2, Fig. 4). Figure 3 illustrates the temporal distribution of the dated oak and ash trees comprising information about estimated germination, dying-off and life span of the single trees. Most dated trees, oak and ash grew in the period between $A D 1$ and $A D 300$ (1949 - 1650 cal. BP). Ages are presented in AD/BC for comparison with archaeological and dendrochronological results from other studies. Furthermore, ages are given in calendar ages BP (cal. BP) for comparison with geological data.
Fig. 2. Raw tree-ring series between $A D$ 200 and AD 400 (1750 - 1550 cal. BP) with alternating periods of wide and narrow tree rings.

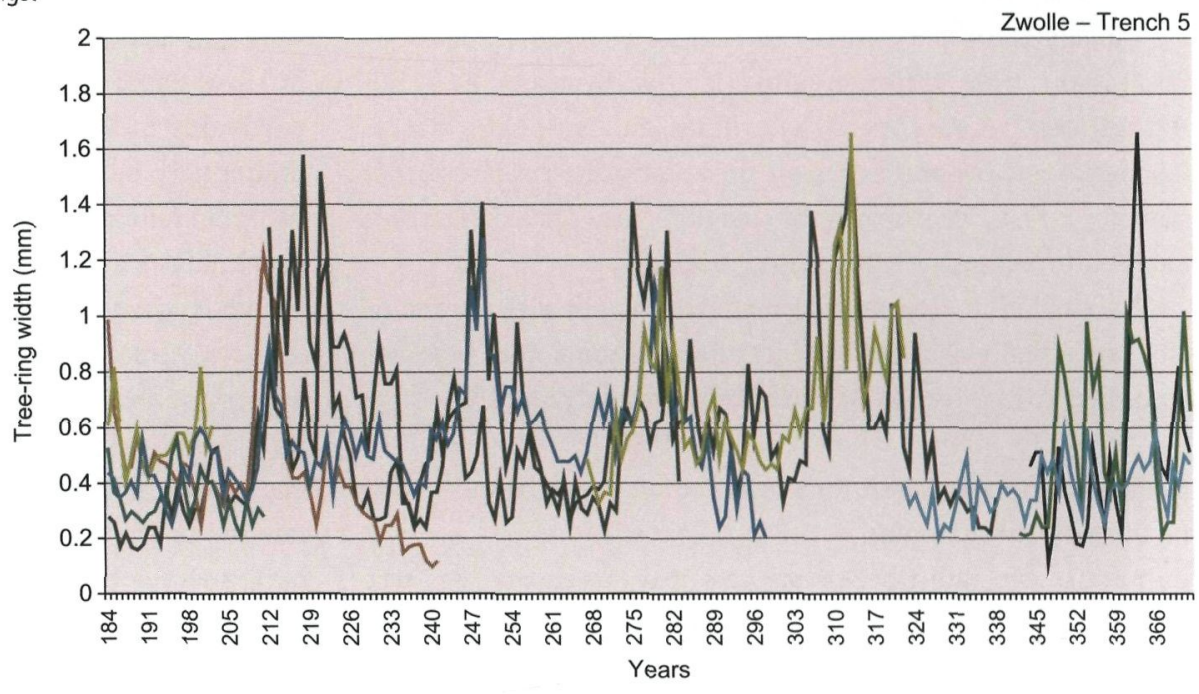




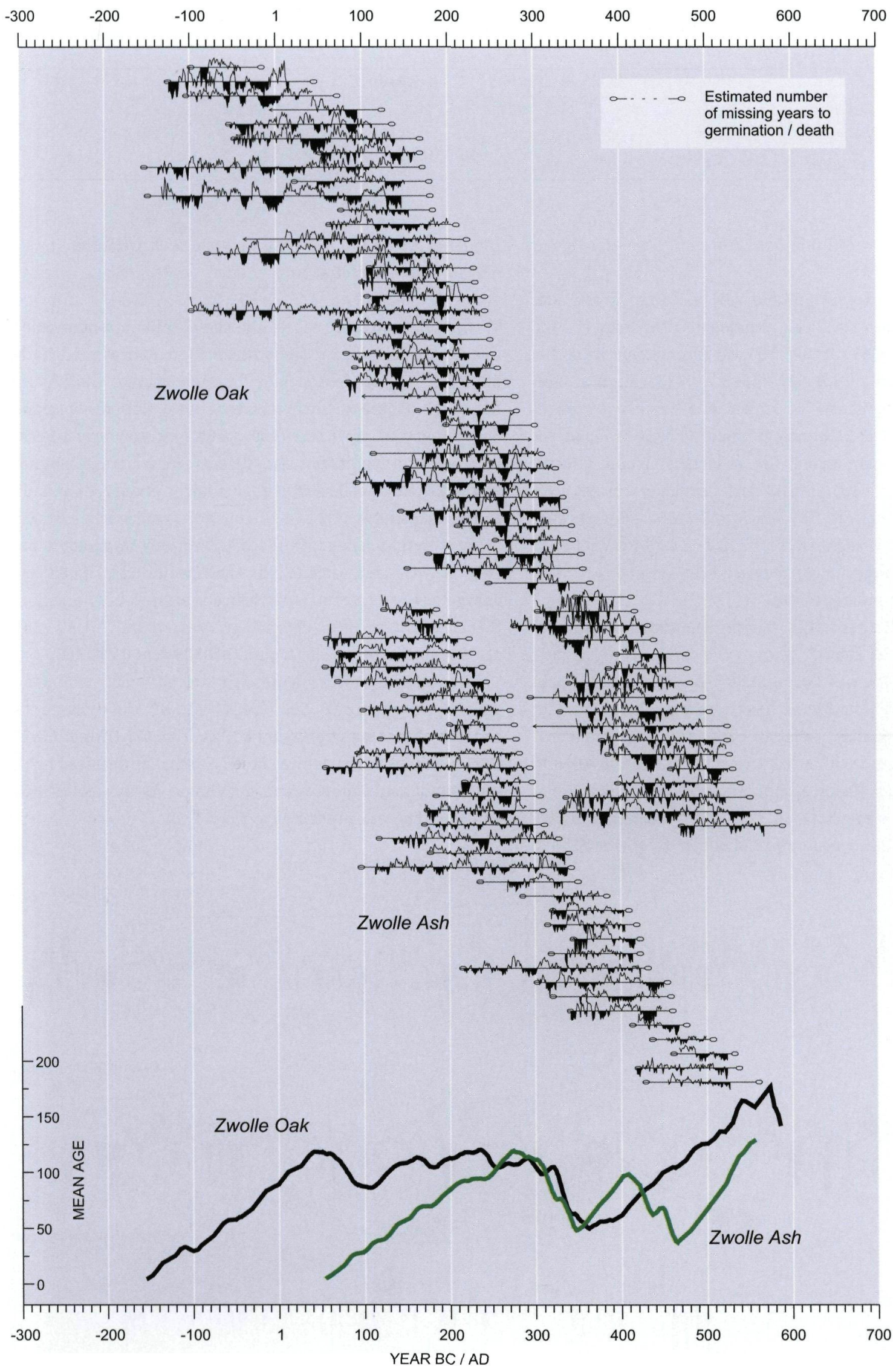

Fig. 3. Temporal distribution of the dated trees through the period of woodland existence (separately for oak and ash) with affiliating mean-age chronologies in the bottom part; see text for further explanation. Growth depressions are marked in black, lines with dots/arrows mark estimated missing rings. Mean-age chronologies are filtered using a 15-year running mean (thick line). 
Table 2. Statistical agreement between Zwolle chronologies and the NW European bog-oak chronology.

\begin{tabular}{llllll}
\hline Chronologies & & Overlap/yrs & correlation & t-value & coeff. parallel. run \\
\hline $\mathrm{N}$ Germany + NL & Zwolle oak & 698 & 0.54 & 17.1 & $69.2 \%$ \\
$\mathrm{~N}$ Germany + NL & Zwolle ash & 469 & 0.40 & 9.5 & $60.1 \%$ \\
Zwolle oak & Zwolle ash & 469 & 0.37 & 8.6 & $59.1 \%$ \\
\hline
\end{tabular}

\section{Comparison between the oak and ash chronologies}

The two site chronologies, 'Zwolle oak' and 'Zwolle ash' are illustrated in figure 4. The oak chronology runs from $131 \mathrm{BC}$ to $\mathrm{AD} 567$ (2082 - 1383 cal. BP); the ash chronology covers the period from AD 58 to AD 527 (1892 - 1423 cal. BP). The striking alternating phases of normal and depressed growth are obvious in both site chronologies but are more pronounced in the oaks. The ash chronology reflects apparent growth depressions at the beginning of the establishment of ash, between AD 58 (1892 cal. BP) and AD 90 (1860 cal. BP), and shortly before ash disappeared after AD 510 (1440 cal. BP). Both depressions were not or only slightly present (AD 510) and certainly less prolonged (AD 60) in the oak chronology. The oaks showed a striking growth depression beginning around AD 530 (1420 cal. BP) prior to the dying-off of the last oak generation at the site Zwolle-Stadshagen (Fig. 4). The oak and ash chronology from Zwolle show a high similarity in both in the high frequency (annual) and the low-frequency variation, i.e. phases with narrow tree rings in oak and ash are mostly synchronous (Table 2, Figs 3 and 4). It is noticeable that the growth depressions in both chronologies occurred quite regularly with a frequency of about 20 to 40 years.

\section{Local versus regional 'signal': comparison with the NW European bog-oak chronology}

The Zwolle ash and especially the Zwolle oak chronology reveal a striking visual and statistical similarity with the NW European bog-oak chronology throughout the whole period (Table 2). Figure 4 illustrates that most periods of growth depression and growth release occur synchronously whereby both, growth depressions and releases, were more pronounced in the Zwolle oak chronology. This latter phenomenon is due to the dampening of the low-frequency variation by averaging many tree-ring series into the NW European chronology. Only two growth depressions in the Zwolle oak (and ash) chronology were not or only scarcely present in the regional NW European bog-oak chronology, one around AD 90 (1860 cal. BP) and another one around AD 300 (1650 cal. BP).

The major growth depression in the oak chronology starting at about AD 530 (1420 cal. BP) just before the collapse of the oak population at Zwolle also occurred in most bog oaks from different sites in NW Europe, as reflected by the synchronous and pronounced depression in the regional NW European bog-oak chronology (Fig. 4).
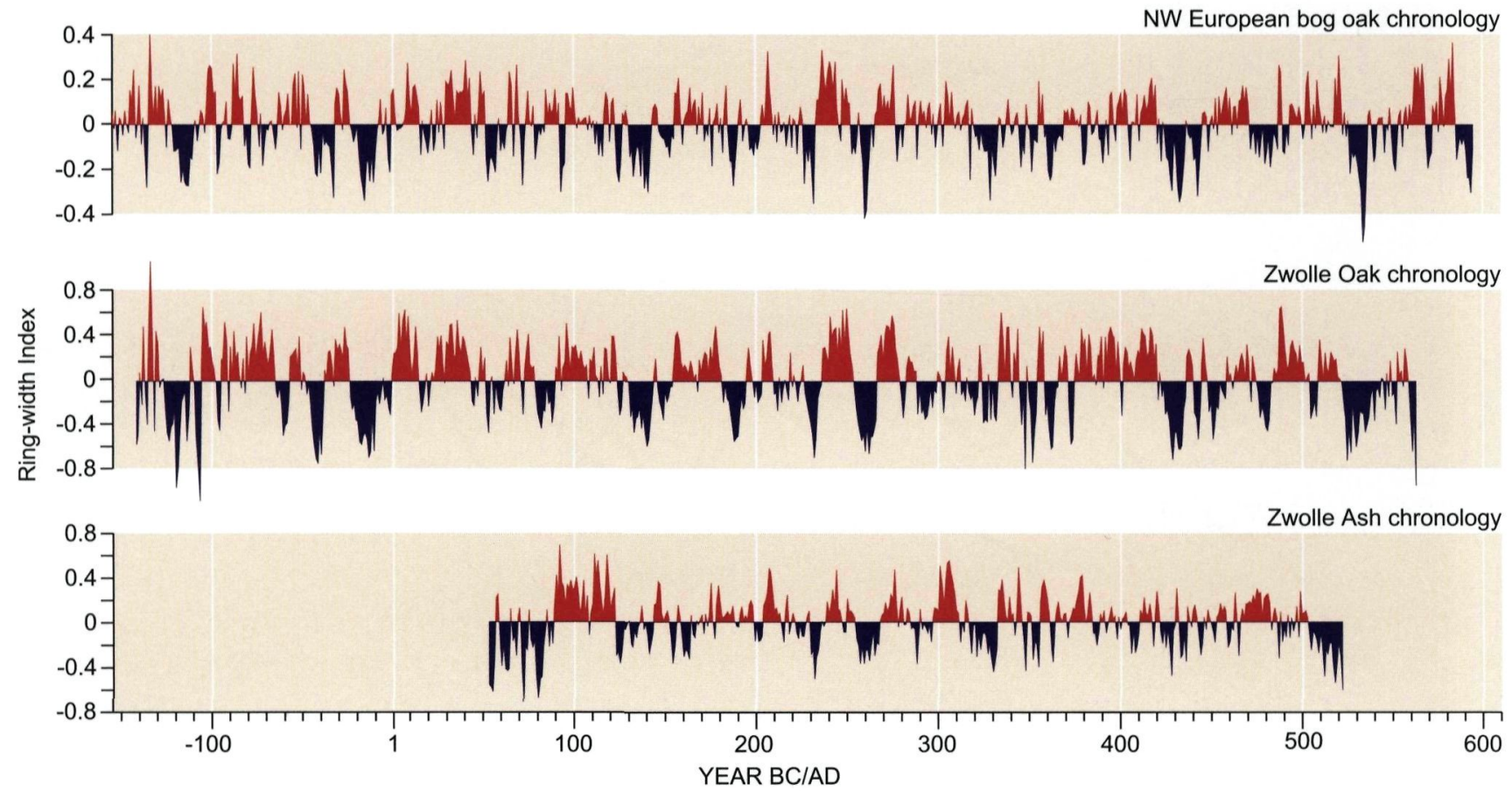

Fig. 4. Comparison of the Zwolle oak and ash chronology with the NW European bog-oak chronology. 


\section{Shifts in population dynamics of oak and ash}

The number of approximately 90 dated oaks and ashes permitted closer examination of trends in the germination and dying-off of the oak and ash populations. Figure 3 shows the temporal distribution of the dated oaks and ashes throughout the existence of the woodland around ZwolleStadshagen. The first impression was that trees were continuously germinating and dying throughout the whole period without distinct (generation) changes in terms of clearly defined accumulated and successive phases of germination and dying-off (GDO). There was no indication of abrupt 'catastrophic' dying-off events, with many trees dying in the same year - not even after AD 530 (1420 cal. BP) when the woodland ceased to exist.

However, by calculating mean-age chronologies it became possible to detect gradual changes in the population dynamics. The mean-age chronologies of oak and ash are illustrated at the bottom of Figure 3.

Two different main patterns of mean age are recognisable: first, a steady increase of mean age in the beginning of the two mean-age chronologies and (in oak) after the AD 300 (1650 cal. BP) depression. This reflects an undisturbed development of a generation of trees which were steadily getting older. Second, a phase with a more or less stable mean age in the oaks between ca. AD 150 and AD 300 (1800 - 1650 cal. BP) reflecting a relatively stable period with trees germinating and dying without distinct GDO events.

Table 3 summarises five major GDO events with the most striking change in mean age occurring - almost synchronously in the oaks and ashes - after AD 300 (1650 cal. BP) with the ashes reacting in $\mathrm{AD} 310$ (1640 cal. $\mathrm{BP}$ ) and the oaks in ca. $\mathrm{AD}$ 330 (ca. 1620 cal. BP). 0aks and ashes of various age died and a new generation of trees established. Most ashes died between $\mathrm{AD} 280$ and $\mathrm{AD} 310$ and a new generation established after $\mathrm{AD}$ 300 (1650 cal. BP). A whole group of oaks died in a relatively short time span between $\mathrm{AD} 330$ and AD 370 (1620 - 1580 cal. $\mathrm{BP})$ with a new - the last - generation establishing almost synchronously around AD 330 (1620 cal. BP). In both species this major GDO event was preceded by or simultaneous with a period of suppressed growth (Figs 3 and 4). Besides this major GD0 event, two others, one minor event in oak around AD 60

Table 3. Population dynamics of oak and ash indicated by GDO (= germination and dying-off) events.

\begin{tabular}{lll}
\hline $\begin{array}{l}\text { Time } \\
\text { Bime }\end{array}$ & (GDO) events \\
BC/AD & (cal. BP) \\
\hline 150 BC & 2100 & Germination of first oaks \\
AD 60 & 1890 & Germination of first ashes and $2^{\text {nd }}$ generation of oak \\
AD 300 & 1650 & Germination and dying-off in oak and ash \\
AD 425 & 1525 & Germination and dying-off in ash \\
AD 540 & 1410 & Dying-off of oaks and ashes, collapse of the woodland \\
\hline
\end{tabular}

(1890 cal. BP) and another major event in ash starting around AD 420 (1530 cal. BP) were apparent; both were associated with growth depressions (Figs 3 and 4).

The change in mean age in oak in $\mathrm{AD} 60$ (1890 cal. BP) mainly reflected the establishment of new oaks together with the first generation of ash during the period between $\mathrm{AD} 60$ and AD 90 (1890 - 1830 cal. BP) (Fig. 3). There was no tendency of more oaks dying at the same time. The change in mean age in the ash population starting in AD 420 (1530 cal. BP) and a second step in reduction in AD 450 (1500 cal. BP) again reflected a 'classic' GDO event with a new - the last - ash generation establishing while all older ashes were dying. A connection between this GDO event and the dramatic growth depressions in oak, ash and the NW European bog oak chronology was evident (Figs 3 and 4).

The last phase of the wetland wood is characterised by a major growth depression starting around AD 530 (1420 cal. BP) in oak and somewhat earlier in ash with many trees dying. The last oak tree survived until ca. AD 586 (1364 cal. BP).

\section{Discussion}

\section{Dendrochronological dating and sample conservation}

Dendrochronology was successfully used to date wood remains from oak and ash trees, even if the material was not preserved perfectly. Wood becomes preserved in waterlogged environments because the biological decay is inhibited as the supply of available oxygen is used up. However, the relatively poor state of conservation of the wood remains from ZwolleStadshagen indicates that either it took a while before the wood got covered and preserved in the peat or that the peat with the wood inside underwent phases of desiccation which led to the deterioration of the wood. The results of the micromorphological study (Kooistra, et al., 2006) support the second assumption by identifying multiple phases when the peat dried out indicated by bioturbation of terrestrial worms. The dendro-dates that were yield from about $20 \%$ of all excavated wood remains indicated that the wetland wood around ZwolleStadshagen existed throughout the period from approximately $150 \mathrm{BC}$ to AD 600 (ca. 2200 - 1400 cal. BP). Hence, datasets and observation from other disciplines, e.g. micromorphology, palynology, wood anatomy and archaeology can be placed in a temporal context. The important role of dendrochronology for dating sub-fossil wood from excavated (natural) woodlands has been stated earlier (e.g. Munaut, 1967; Lageard, et al., 1995). However, the potential of dendrochronology is much greater (Sass-Klaassen, 2002). In the context of landscape reconstruction dendrochronology can be used to answer questions about changes in site ecology and climate (e.g. Heyworth, 1978; Schweingruber, 1996; Leuschner \& SassKlaassen, 2003). 


\section{Identification of growth-influencing site factors}

\section{Ecological interpretation of the growth pattern}

The oaks and ashes showed the characteristic growth pattern of bog oaks with alternating periods of normal and depressed growth that occurred synchronously in all trees. The latter aspect indicates the existence of $a(n)$ (complex of) environmental factor(s) that strongly limited the growth of oak and ash in the woodland of Zwolle-Stadshagen during certain periods. But - as this happens to be the general growth pattern of most sub-fossil oaks from NW Europe (Baillie, 1995; Pilcher et al., 1996; Leuschner et al., 2002) it must be connected to the specific environment where these trees grew and subsequently were preserved. Wetland woods form a specific ecosystem: the trees grow on or close to the peat that, on the one hand, was (temporarily) dry enough to support even long-living trees, and on the other hand, was (temporarily) wet enough to provide a medium to preserve the remains of these trees for thousands of years. The trees adapted to these extreme site conditions by forming shallow roots that extended horizontally far into the upper soil layer, which dried out periodically every summer. The oak and ash from Zwolle-Stadshagen showed this same morphological pattern (Kooistra et al., 2006). This made them susceptible to wind and changes in hydrology. There is however no indication that the trees in Zwolle-Stadshagen were wind thrown. Most root systems were found in a horizontal position and the stems were not systematically orientated according to the main wind direction (Kooistra et al., L.I., pers. comm.). Thus, changes in hydrology both towards drier en wetter conditions were considered to have a major impact on tree growth and dying-off. Temporary high groundwater levels are suggested being responsible for creating both depressed growth and optimal preservation conditions (Pilcher et al., 1996; Leuschner et al., 2002).

In this study strong evidence was found for a link between recurrent growth depressions in oaks and ashes and phases of waterlogged soil conditions. The results of the micromorphological study (Kooistra et al., 2006) confirmed that (periodic) water logging during the first phase of the woodland in Zwolle-Stadshagen occurred when the groundwater level reached the soil surface, whereas in the second part, after ca. AD 300 (ca. 1650 cal. BP), frequent flooding, indicated by thin clay layers in the peat, played an important additional role. Together with this flooding drainage of the area occurred, which made the hydrological situation even more complex (Kooistra et al., 2006). Interestingly, these striking changes in hydrological circumstances neither affected the growth level nor the general growth pattern of the trees. The oaks and ashes kept forming the characteristic prolonged growth depressions. Changing hydrological conditions also affected peat accumulation in this area: longer phases with a relatively low groundwater level and/or superficial drainage and/or the absence of flooding caused stagnation of peat growth. The uppermost soil layer dried out and bioturbation occurred. These drier periods must be connected with phases of favourable tree growth (tree-ring widths between 1.5 and $2 \mathrm{~mm}$ !) when a lot of nutrients were released from the decomposition of the peat and the increasing rooting area, while the only superficial drying-out of the top of the peat layer did not seriously affect the water availability for the shallow rooting trees.

\section{Changes in site hydrology - Physiological consequences for the trees}

The results for Zwolle-Stadshagen indicate periodic changes in site hydrology at Zwolle-Stadshagen whereby relatively dry periods were interrupted by wetter periods about every 20 to 40 years. Interestingly, many trees were able to survive these recurrent wet periods and experienced up to seven wet periods throughout their life. Taking into account the ecological setting in these wetland woods growth depressions are assumed to be the result of prolonged (winter)flooding or prolonged phases of high groundwater in:spring which led to (i) a delay in growth initiation and thus a shortage of the vegetation period and/or (ii) root damage due to lack of oxygen in the root zone during the beginning of the vegetation period when tree growth had already started. The first assumption is supported by the results of an isotopic study on the same material where the lack of a clear isotopic 'stress signal' is discussed as the consequence of a drastic reduction in length of the growing period (Sass-Klaassen et al., 2005). As concerning the second assumption, root damage, Crawford et al. (2003) considered that roots do not only die due to prolonged anoxic conditions during flooding, but that root growth that already started under anoxic conditions leads to a marked decrease in carbohydrate reserves. Crawford \& Braendle (1996) mentioned that once these carbohydratedepleted roots are exposed to air again an extensive dieback of the root system occurs presumably due to post-anoxic injury. Another possible reason for the long-term growth depressions can be the dying-off of mycorrhiza as a consequence of prolonged wet conditions. Mycorrhizas are very sensitive to changes in the soil hydrology (Vasilas et al., 2004).

\section{Changes in site hydrology - Local or regional triggers?}

The striking match of alternating phases of favourable and depressed growth between the bog oaks and ashes from Zwolle-Stadshagen and the bog oaks from other wetland sites in the Netherlands and Germany (NW European bog-oak chronology) proved that not local but one or more large-scale regional factors had to be the trigger for these growth reactions. Consequently, local changes such as beaver activities or insect 
attacks can be excluded as possible reasons for the growth depressions. The latter can also be excluded due to the fact that insects usually affect specific species, i.e. a simultaneous attack on oak and ash would have been very unlikely.

The lack of strong local 'signals' in the tree-ring series also made it unlikely that humans exploited the woodlands and the surrounding area in Zwolle-Stadshagen. Extensive cutting activities in the woodlands or the higher surrounding areas (with the effect of erosion) could have had an impact on local site hydrology. Spurk et al. (2002) discussed the significant impact of men in river catchment areas since ca. 1000 BC (2950 cal. BP). However, there was no indication in the growth pattern or other evidence, i.e. stumps or charcoal that point to the fact that humans used the woodland of Zwolle-Stadshagen during the investigated period (Kooistra et al., 2006). Before a further characterization of the triggering regional factor the population dynamics of the oaks and ashes from ZwolleStadshagen will be discussed.

\section{Population dynamics of oak and ash - An indicator of major shifts in site ecology}

Interesting information was provided by the temporal distribution of the dated oak and ash trees - specified by the mean age chronology - in combination with the tree-ring pattern. It was possible to identify five main GD0 events (see Table 3) in the oaks and ashes with all of them being preceded by or synchronous with growth depressions in the surviving trees. All these events could be related to contemporary changes in the pollen and soil archive and reflect shifts in ecological conditions in the wetland woods of Zwolle-Stadshagen (Kooistra et al., 2006). Most of these GD0 are also documented as periods when site conditions changes profoundly on other wetland sites in NW Europe.

\section{The environmental history of the wetland wood at Zwolle-Stadshagen}

In the first phase of the wetland wood oak was the dominant species in comparison to ash. The oaks that germinated around 150 BC (ca. 2100 cal. BP) on peaty sand and were subsequently preserved in the peat established during a period that was described as humid in the Netherlands (Jelgersma et al., 1970). Leuschner et al. (1987) found that many oaks on different sites in NW Germany were dying due to increasing wetness between $300 \mathrm{BC}$ and ca. 100 BC (2250 - 2050 cal. BP) and discussed an increase in precipitation as the underlying trigger. Moreover, Leuschner et al. (2002) pointed out $150 \mathrm{BC}$ (2100 cal. BP) as a major GDO (germination and dying-off) event in the NW European bog-oak populations meaning that at this time many (old) oaks died and a new generation of young trees established. The micromorphological results from the Zwolle site confirmed that the first oaks established around the time when the groundwater level was already high and the coversand turned into a sandy peat (Kooistra et al., 2006). The presence of a fluctuating but generally high groundwater level is indicated by the recurrent growth depressions that were already occurring in the first generation of oak that grew on (peaty) sand. These oaks were the first to be preserved in the peat which started to grow between ca. AD 6 and AD 102 (1944 - 1848 cal. BP) (Kooistra et al., 2006).

About 200 years later, around AD 60 (1890 cal. BP), the first ashes appeared on the peaty soil together with the second generation of oak, indicated by a drop of the mean-age chronology of the oaks (Fig. 4). Generally, ash is known as a species that may withstand winter flooding but is susceptible to periods of waterlogging (Weeda et al., 1988). It was, however, commonly found on wet woodlands where nearby rivers had a considerable influence on site hydrology indicated by the presence of clay in the peat (Leuschner, pers. comm.). The striking growth depressions in the ashes at the beginning of their establishment suggested sub-optimal growth conditions. Since peat formation started around this time it must have been that these new generations of ash and oak established on somewhat higher spots in the peat.

The greatest change occurred around AD 310 (1640 cal. BP) in the ash and in $\mathrm{AD} 330$ (1620 cal. BP) in the oak population when all trees also show strong growth reductions (Fig. 4). Leuschner \& Sass-Klaassen (2003) found a synchronous GD0 event on the site Hammah, near Stade in Northern Germany, when a quickly expanding raised bog killed most oaks. This forceful GDO event most likely reflects a striking change in site hydrology at Zwolle-Stadshagen. Taking into account the micromorphological results (Kooistra et al., 2006) this could be the time when frequent flooding in combination with drainage of the woodland started. Alternating phases of dry conditions with the consequence of peat decomposition and bad pollen conservation (Kooistra et al., 2006) and wet conditions with high groundwater level en/or (prolonged) flooding created a complex hydrological situation. The complexity of the situation was moreover enhanced by smallscale differences in site topography. Seed germination and especially the establishment of new oaks and ashes could be favoured by both, prolonged dry periods as well as prolonged wet periods. Trees, especially oaks and ashes in modern wetland woods favourably germinate on somewhat higher and thus dryer drier spots (Sass-Klaassen, 2003, 2004) which makes them less susceptible to a temporary high groundwater level or flooding and could provide better chances to survive wet periods (Leuschner \& Sass-Klaassen, 2003). This fits the observation that the last generation of ash in ZwolleStadshagen was found exclusively in the somewhat higher located trench 5 (Kooistra et al., 2006).

However, a second important factor that influences tree germination and establishment is light. Considering this aspect it could well be that wetter than normal periods with the 
effect of prolonged waterlogging favoured the establishment of oak (and ash) seedlings. Prolonged waterlogging has been found to reduce competition by flood-intolerant tall herbs, ferns or shrubs (e.g., Rubus spp.) (Siebel \& Bouwma, 1998). This last phenomenon was observed in a modern wetland oak site, where many old oaks died due to a rising groundwater table - with the result that gaps were created - while a new oak generation established exclusively on very wet spots with a lack of ground cover (Sass-Klaassen, unpubl. report).

Hence, either prolonged dry or prolonged wet conditions may favour germination and establishment of single trees or even a new tree generation. However, it is very likely that the intensity of the hydrological change played a major role. This holds also true for the period after AD 300 (1650 cal. BP) when the woodland of Zwolle-Stadshagen started to experience a regime of frequent flooding. It is assumed that all growth depressions and the last abrupt change in mean age in the ashes at AD 420 (1530 cal. BP) were linked to periods of (spring and summer) flooding. The increased flooding frequency indicated by a greater density of clay bands in the peat meant that hardly any oaks established after AD 400 (1550 cal. BP) until the collapse of the woodland. An inhibition of seed germination and tree establishment during periods with high flooding frequency has been earlier described for lowland trees in the U.S. (Gill, 1970; Kozlowski, 1984).

All oaks and ashes at Zwolle-Stadshagen died after showing a dramatic growth depression starting after AD 530 (1420 cal. BP) which also occurred in oaks from many sites in NW Europe, including Ireland (Leuschner et al., 2002). The European record of population dynamics of sub-fossil oaks marked the year $A D$ 540 as a major GD0 event all over NW Europe. It probably reflects a dramatic climate change after a volcano and/or comet event (Baillie, 1994; 1996; 1999; Keys, 1999). Micromorphological results indicate that the woodland at Zwolle-Stadshagen became at this time completely inundated and drowned when a shallow freshwater lake developed (Kooistra et al., 2006).

\section{Conclusions}

By using dendrochronology it was possible to precisely date the wood remains of oak and ash that grew in the wetland wood at Zwolle-Stadshagen. Moreover it was possible to link the specific growth characteristics and shifts in population dynamics of the oaks and ashes to corresponding changes in site hydrology. By comparing the tree-ring record of ZwolleStadshagen with the regional NW European bog-oak chronology it became obvious that most changes in growth activity and thus site hydrology at Zwolle-Stadshagen were not local, i.e. site specific, but reflect large-scale changes in hydrology that occurred synchronously on different sites in NW Europe. Due to the fact that most of the growth depressions and also the collapse of the woodland after $\mathrm{AD} 530$ were also present in the NW European bog oak record it has to be concluded that the hydrological history of the Zwolle site was triggered by a large-scale (climatic) factor. Inundations were at least partly initiated by large-scale variations in climate conditions, namely changes in precipitation that may have affected river run-off and the ground-water level. By studying the population dynamics of oaks and ashes in Zwolle-Stadshagen it became obvious that site hydrology showed a drastic change after $\mathrm{AD} 300$, when the woodland became frequently flooded. This was the beginning of the end of the woodland of ZwolleStadshagen, which started to drown completely after AD 530. The timing of the collapse of the woodland at ZwolleStadshagen again suggested triggering by a large-scale factor since at this time a global tree-ring downturn took place.

\section{Acknowledgements}

This research is part of a project funded by the Netherlands Organisation of Scientific Research (NWO/AWL 750.700.04). The municipality of Zwolle supported part of this project via the Promotion of Archaeology Foundation (Stichting Promotie Archeologie). Additional financial support for writing this article was provided by Alterra, DL0 programme no. 382. We would like to thank Dr H. H. Leuschner, University of Göttingen, Germany, for providing his data, assisting with the statistical analysis and plots as well as for improving the manuscript.

\section{References}

Baillie, M.G.L., 1994. Dendrochronology raises questions about the nature of the AD 536 dust-veil event. The Holocene 4: 212-217.

Baillie, M.G.L., 1995. A Slice through Time: dendrochronology and precision dating. Batsford (London): $176 \mathrm{pp}$.

Baillie, M.G.L., 1996. Extreme environmental events and the linking of the tree-ring and ice-core records. In: Dean, J.S., Meko, D.M. \& Swetnam, T.W. (eds): Tree Rings, Environment, and Humanity. Radiocarbon, Department of Geosciences, The University of Arizona (Tucson): 703-711.

Baillie, M., 1999. Exodus to Arthur: catastrophic encounters with comets. Batsford (London): $272 \mathrm{pp}$.

Billamboz, A., 1996. Tree rings and pile-dwellings in south-western Germany: Following in the footsteps of Bruno Huber. In: Dean, J.S., Meko, D.M. \& Swetnam, T.W. (eds): Tree Rings, Environment, and Humanity. Radiocarbon 1996, Department of Geosciences, The University of Arizona (Tucson): 471-483.

Billamboz, A., 2002. Die dendrochronologische Heterokonnexion verschiedener Holzarten am Beispiel der metallzeitlichen Pfahlbausiedlungen Südwestdeutschlands. Aussagen aus Paläeoklimatischer und -ökologischer Sicht. In: Bräuning, A. (ed.): Zum Stand der Anwendung der Dendrochronologie in den Geowissenschaften. Stuttgarter Geogrqphische Studien 133: 43-57.

Crawford, R.M.M. \& Braendle, R., 1996. 0xygen deprivation stress in a changing climate. Journal of Experimental Botany 47: 145-159.

Crawford, R.M.M., Jeffree, C.E. \& Rees, W.G., 2003: Paludification and forest retreat in Northern oceanic environments. Annals of Botany 91: 213-226. 
Friedrich, M., Remmele, S., Kromer, B., Spurk, M., Hofmann, J., Hurni, J-P., Kaiser, K.F. \& Küppers, M., 2004. The 12.480-year Hohenheim oak and pine tree-ring chronology from Central Europe - A unique annual record for radiocarbon calibration and palaeoenvironment reconstructions, Radiocarbon 46: 1111-1122.

Fritts, H.C., 1976. Tree Rings and Climate. Academic Press (New York): 567 pp. Gill, C.J., 1970. The flooding tolerance of woody species - a review. Forestry Abstracts 31: 671-688.

Grissino-Mayer, H.D., 2001. Evaluating crossdating accuracy: A manual and tutorial for the computer program COFECHA. Tree-Ring Research 57: 205-221.

Heyworth, A., 1978. Submerged forests around the British Isles: their dating and relevance as indicators of post-glacial land and sea level changes. BAR International Series 51: 279-288.

Holmes, R.L., 1983. Computer-assisted quality control in tree-ring dating and measurement. Tree-Ring Bulletin 43: 69-78.

Jansma, E., 1995. RemembeRINGs. The Development and Application of Local and Regional Tree-Ring Chronologies of Oak for the Purposes of Archaeological and Historical Research in the Netherlands. PhD. Dissertation. University of Amsterdam. Nederlandse Archeologische Rapporten (NAR) 19: 149 pp.

Jansma, E., 1996. An 1100-Year Tree-Ring Chronology of Oak for the Dutch Coastal Region. In: Dean, J.S., Meko, D.M. \& Swetnam, T.W. (eds): Tree Rings, Environment, and Humanity. Radiocarbon, Department of Geosciences, The University of Arizona (Tucson): 769-778.

Jelgersma, S., de Jong, J., Zagwijn, W.H. \& van Regteren Altena, J.F., 1970. The coastal dunes of western Netherlands; Geology, vegetational history and archaeology. Mededelingen Rijksgeologische Dienst NS. 21: 93-167.

Keys, D., 1999. Catastrophe: an investigation into the origins of the modern world. Century (London): $368 \mathrm{pp}$.

Kooistra, M.J., Kooistra, L.I., Rijn, P. van \& Sass-Klaassen U., 2006. Woodlands of the past. The excavation of wetland woods at Zwolle-Stadshagen (the Netherlands) - Environmental reconstruction. Netherlands Journal of Geosciences 85 (1): 37-60.

Kozlowski, T.T., 1984. Flooding and plant growth. Academic Press (New York): $356 \mathrm{pp}$.

Lageard, J.G.A., Chambers, F.M. \& Thomas, P.A., 1995. Recording and reconstruction of wood macrofossils three-dimensions. Journal of Archaeological Science 22: 561-567.

Leuschner H.H., 1992. Subfossil trees. In: Bartholin. T. (ed.): Tree-Rings and Environment. Proceedings of the International Dendrochronological Symposium, Ystad, South Sweden. Lundqua Report 34: 193-197.

Leuschner, H.H., Sass-Klaassen, U., Jansma, E., Baillie, M.G.L. \& Spurk, M., 2002. Subfossil European bog oaks: population dynamics and long-term growth depressions as indicators of changes in the Holocene hydro-regime and climate. The Holocene 12: 695-706.

Leuschner, H.H., Delorme, A. \& Höfle H.C., 1987. Dendrochronological study of oak trunks found in bogs in Northwest Germany. Proceedings of the International Symposium on ecological aspects of tree ring analysis, New York: 298-318.

Leuschner, H.H. \& Sass-Klaassen U., 2003. Subfossil oaks from bogs in NW Europe as a (dendro)archaeological archive. In: Bauerochse, A. \& Hassmann H. (eds), Peatlands; Proceedings of the Peatland Conference 2002 in Hannover: 210216. Rahden/Westf.:Leidorf, Germany: 210-216.
Munaut, A.V., 1967. Etude paleo-ecologique d'un gisement tourbeux situe á Terneuzen (Pays-Bas). [Paleoecological study of a peat deposit located in Terneuzen (the Netherlands)] Berichten van de Rijksdienst voor het Oudheidkundig Bodemonderzoek 17: 7-27.

Pilcher, J.R., Baillie, M.G.L., Brown, D.M. \& McCormac, F.G., 1996. Hydrological data from the long Irish subfossil oak records. In: Dean, J.S., Meko, D.M. \& Swetnam, T.W. (eds): Tree Rings, Environment, and Humanity. Radiocarbon, Department of Geosciences, The University of Arizona (Tucson): 259-264.

Pilcher, J.R, Baillie, M.G.L., Schmidt, B. \& Becker, B., 1984. A 7272-Year treering chronology for Western Europe. Nature 312: 150-52.

Riemer, T., 1994. Ueber die Varianz von Jahrringbreiten. Statistische Methoden fuer die Auswertung der jährlichen Dickenzuwaechse von Bäumen unter sich ändernden Lebensbedingungen. [Variance of tree-ring widths. Statistical methods for evaluation of the annual increment of trees under changing living conditions.] Ph.D. dissertation, University of Göttingen, Germany. Berichte des Forschungszentrums Waldökosysteme, Reihe A 121 (Göttingen, Germany): 375 pp.

Rinn, F., 1996. TSAP - Time Series Analysis Program. For applications in forestry tree-ring laboratories and dendrochronology. Rinntech (Heidelberg).

Sass-Klaassen, U., 2002. Dendroarchaeology - success in the past and challenges for the future. Dendrochronologia 20: 87-93.

Sass-Klaassen, U., 2003. Veeneiken - sleutel tot het verleden landschap en klimaat? Nederlands Bosbouwtijdschrift 75: 32-38.

Sass-Klaassen, U., 2004. Exploring oaks in modern wetland woods in Europe to trace the climate signal in tree-ring series of sub-fossil bog oaks. In: Jansma, E. \& Gaertner H. (eds) TRACE, Tree Rings in Archeology, Climatology and Ecology 2: 67-72.

Sass-Klaassen, U. Poole, I., Wils, T. Helle, G., Schleser, G.H. \& Van Bergen P.F., 2005. Carbon and oxygen isotope dendrochronology in sub-fossil bog oak tree rings - a preliminary study. IAWA Journal 26: 121-136.

Schweingruber, F.H., 1996. Tree Rings and Environment. Dendroecology. Paul Haupt Verlag (Berne): 609 pp.

Siebel, H.N. \& Bouwma, I.M., 1998. The occurrence of herbs and woody juveniles in a hardwood floodplain forest in relation to flooding and light. Journal of Vegetation Science 9: 623-630.

Spurk, M., Leuschner, H.H., Baillie, M.G.L., Briffa, K.R. \& Friedrich, M., 2002. Depositional frequency of German subfossil oaks: climatically and nonclimatically induced fluctuations in the Holocene. The Holocene 12: 707-715.

Vasilas, B., Vasilas, L., Thompson, J., Rizzo, A., Fuhrmann, J., Evans, T., Pesek, J. \& Kunklea, K., 2004. Ectomycorrhizal mantles as indicators of hydrology for jurisdictional wetland determinations. Wetlands 24: 784-795.

Weeda, E., Westra, R., Westra, C. \& Westra, T., 1988. Nederlandse Oeologische Flora; wilde planten en hun relaties, deel 1-5, IVN (Amsterdam). 